\title{
The use of various types of hip prostheses depending on the patient's age and level of everyday activity
}

\section{Zastosowanie różnych rodzajów endoprotez stawu biodrowego w zależności od wieku i codziennej aktywności pacjentów}

\author{
Tomasz Poboży ${ }^{1}$, Maciej Kielar ${ }^{2,3}$ \\ ${ }^{1}$ Department of Orthopaedic Surgery, Surgery Clinic, Medicover Hospital, Warsaw, Poland \\ Head of the Clinic: Prof. JKU Maciej Kielar MD, PhD \\ 2Department of Oncology and Nursing Oncology, Institute of Nursing and Obstetrics, Faculty of Medicine and Health Science, \\ Jan Kochanowski University, Kielce, Poland \\ Head of Department: Prof. JKU Maciej Kielar MD, PhD \\ ${ }^{3}$ C Chair and Clinic of General and Vascular Surgery, II Faculty of Medicine with the English Division, Medical University of Warsaw, \\ Warsaw, Poland \\ Head of the Chair: Prof. MUW Piotr Ciostek MD, PhD
}

Key words: hip joint, hip replacement, hip prosthesis, osteoarthritis, arthroplasty.

Słowa kluczowe: staw biodrowy, endoprotezoplastyka stawu biodrowego, protezy biodra, zwyrodnienia stawów, aloplastyka.

\begin{abstract}
Hip replacement surgery is becoming more and more common in clinical practice, as a growing number of patients qualify to receive this form of treatment. This is because the aging of the society, high prevalence of overweight, and little physical activity contribute to the development of osteoarthritis. Moreover, patients have come to expect good quality of life even at advanced age. Thanks to progress in surgical techniques, these expectations can now be met. Endoprosthesis selection apart from medical indications - must be based on the patient's age, everyday activity, and further plans. There are two main types of clinical situations where hip arthroplasty is performed; these are hip joint degeneration and femoral neck fracture. This article aims to present current options of total hip replacement to healthcare professionals who wish to learn more on the subject, including physical therapists, nurses, and professional caretakers for patients with walking difficulties.
\end{abstract}

\section{Streszczenie}

Endoprotezoplastyka stawu biodrowego jest stosowana coraz częściej w praktyce lekarskiej ze względu na pacjentów wymagających tej formy leczenia operacyjnego. Starzenie się społeczeństwa, rozwój choroby zwyrodnieniowej w wyniku nadwagi i braku ruchu, przy jednoczesnym oczekiwaniu, aby leczenie pozwalało odzyskać sprawność, oraz postęp technologiczny w chirurgii powodują, że zwiększa się liczba endoprotezoplastyk. Poruszanie się bez bólu jest przedmiotem zainteresowania lekarzy rodzinnych i geriatrów w kontaktach z pacjentami w średnim i starszym wieku. Przy wyborze odpowiedniej endoprotezy, oprócz wskazań medycznych, ważne powinny być wiek, płeć, codzienna aktywność i plany życiowe pacjentów. Protezy stawu biodrowego są stosowane w dwóch przypadkach - po zniszczeniu stawu przez chorobę i po złamaniach szyjki kości udowej. Celem artykułu jest przybliżenie aktualnych możliwości aloplastyki stawu biodrowego lekarzom różnych specjalności pragnącym poszerzyć swoją wiedzę, rehabilitantom, pielęgniarkom i osobom, które na co dzień profesjonalnie opiekują się osobami z problemami w samodzielnym poruszaniu się.

\section{Introduction}

Total hip replacement surgery is one of the most common major orthopedic procedures. According to the Polish Central Database for Arthroplasty Procedures compiled by the National Health Fund (NFZ), in the year 2010,there were 49,076 arthroplasty procedures conducted in Poland, out of which 36,854 were hip replacement procedures [1]. Such procedures were performed in 286 centers, with some additional procedures conducted in non-public facilities, not included in the NFZ-funded procedure-reimbursement program. Last year, the number of such procedures exceeded 50,000. Although joint damage that qualifies the patient for prosthesis implantation may result from various conditions, it is generally accepted that 
hip arthroplasty should be considered in situations where pain does not improve despite conservative treatment and the patient's mobility is limited, for instance by hip contractures. Another type of condition dictating total hip replacement, i.e. femoral neck fracture, is a result of extended life-expectancy, which leads to a higher prevalence of osteoporosis, which in turn contributes to the higher incidence of fractures. In either clinical situation, the often life-saving treatment that can restore physical performance is total hip replacement. In current orthopedic practice the most common types of conditions that qualify a patient for total hip replacement are: hip joint damage due to osteoarthritis and femoral neck fracture [2, 3].

Osteoarthritis, or degenerative bone disease, can be divided into idiopathic (or primary) condition, where the causative factor cannot be determined, and secondary condition, where joint damage is a result of a specific pathology, such as developmental dysplasia of the hip, femoral head a vascular necrosis, a history of slipped capital femoral epiphysis, and inflammatory conditions, such as rheumatoid arthritis orpsoriatic arthritis [4-7]. Studies show [5, 6, 8-13] that osteoarthritis of the hip affects mostly people over 50 years of age; in fact, it may develop at any age. Recent findings demonstrate an increased age-range of patients undergoing surgery: on the one hand, there are more younger patients who qualify for surgery because their overweight and a lack of exercise accelerate the process of joint surface damage, on the other hand, new surgery techniques and safer anesthesia mean that even the very elderly can qualify for hip replacement procedures - there have been reports of this procedure conducted in patients about 100 years old $[14,15]$.

Conservative treatment may bring relief in early stages of osteoarthritis $[4,12,13]$. However, it is not effective enough in more advanced stages. Development of regularly recurring problems with everyday functioning (such as pain requiring systematic administration of analgesics, discomfort at night preventing sleep, limited joint mobility, limb axis misalignment, and development of contractures) is considered to be an absolute indication for orthopedic surgery, which involves surgical replacement of the disease-damaged joint with a hip joint prosthesis $[13,16]$.

\section{Hip replacement surgery}

Hip prosthesis implantation involves replacement of the disease-damaged parts of the hip joint with prosthetic implants: the acetabular cup and the femoral head. The procedure involves acetabular reaming and insertion of a (typically metal) acetabular cup, which is subsequently fitted with a (typically polyethylene or ceramic) acetabular insert. The femoral neck is sawed off at the base and removed together with the femoral head. Inside the femoral shaft a canal is formed to receive the stem of the implant, which is inserted and fixed in place. The stem type may facilitate wedging the implant tight into the prepared canal, without the need to use bone cement (so-called uncemented, or cementless, fixation). Alternatively, the implant may require securing it in the bone canal with a special fixation polymer (so-called cemented fixation). Cementless implant fixation is currently more common.

Once the prosthesis stem is implanted axially into the femoral shaft, a metal or ceramic ball (i.e. a prosthetic femoral head) is attached to its end. This combined prosthetic set is then inserted into the previously prepared acetabular cup and, after proper prosthesis alignment and fit have been verified, the surgical wound is closed in layers [17].

In the past, a hip replacement procedure required extensive tissue dissection to obtain good access to the relevant structures. Such a procedure constituted a major surgical injury, with blood loss often requiring blood transfusion, and the postoperative mobilisation and recuperation periods were long. The surgical wound often extended $30-40 \mathrm{~cm}$ in length, which produced both a major surgical injury and poor aesthetic effect.

Now, the so-called minimally-invasive approach to hip replacement surgery is becoming more and more common [18]. Used properly, this surgical technique minimises injury to soft tissues, especially muscles, as the intermuscular approach allows for access to hip joint structures in a minimally-traumatic way, without negatively affecting post-operative motor function. The use of a minimally-invasive approach reduces surgical injury, procedure duration, intraand postoperative blood loss, and postoperative pain, which typically accelerates tissue healing and facilitates early mobilisation. Moreover, the minimallyinvasive approach produces a smaller scar, often just a few centimetres long, which many patients find important for aesthetic reasons.

However, minimally-invasive hip arthroplasty may not be technically possible in some patients, such as in the obese or in patients with significant hip joint deformities. Dictated by a number of anthropometric parameters and the patient's health status, the selection of an appropriate surgical technique and implant is key for a successful clinical and functional outcome.

\section{Hip prosthesis types}

In terms of types of prosthesis fixation to native tissue, hip arthroplasty has been traditionally classified into cemented, cementless, and hybrid fixation.

We can also distinguish total hip arthroplasty and hemiarthroplasty, depending on which parts of the joint require replacement [19-21].

Another classification, which is based on the extent of bone resection, seems to be more applicable. 
The following section lists various prosthesis types used in hip arthroplasty, depending on the surgical approach used. These various prostheses and surgical techniques have been organised depending on the extent of bone resection.

\section{Resurfacing arthroplasty}

One example of bone-preserving procedure, requiring only a limited resection of the proximal end of the femur, is so-called hip resurfacing arthroplasty [22]. It involves shaving off the surface of the femoral head and placing a large metal cap on the thus prepared bone to create a new, artificial joint. The result of such a procedure is a metal head (or ball) set in a metal socket.

Bone preparation for acetabulum placement is not much different from that in total hip arthroplasty; however, the metal acetabulum does not have a polyethylene or ceramic insert - instead, its inner surface is smooth and is in direct contact with the large metal head, which is set onto the proximal end of the femur. The fact that the procedure involves neither a total removal of the native head of the femur nor prosthesis stem insertion might suggest that it is less invasive and the patient should recover more rapidly. However, resurfacing arthroplasty is typically associated with a more severe soft tissue injury. Thus, following a period of initial enthusiasm and attempts to popularise this technique into clinical practice, there came a period of critical assessment of treatment outcomes, which resulted in a dramatic reduction of indications for, and the number of, these procedures. The use of this surgical approach is currently on the decline, as most manufacturers of this type of prosthesis are withdrawing their products from the market. This is due to the possible complications associated with the release of heavy metal ions from prosthesis alloys, which may cause local reactions. Moreover, heavy metal ions absorbed into the bloodstream may lead to harmful systemic effects. Although the concentration of these ions is not high enough to pose a direct threat to the patient's health (linear wear is typically below $1 \mu \mathrm{m} /$ year), in the case of pregnancy in a female patient teratogenic effects on the foetus cannot be excluded. Therefore, resurfacing arthroplasty should not be used in women of childbearing potential. The use of this technique in postmenopausal women can also be questionable, due to a higher prevalence of osteoporosis in this patient group, which may lead to complications such as femoral neck fracture. Despite the availability of bone density scans prior to hip resurfacing arthroplasty in order to exclude osteoporosis, a number of studies demonstrated this type of procedures to have higher complication rates in comparison with other types of hip replacement procedures. This fact was emphasised by a large statistical analysis published in The Lancet in March 2012 [23].
Resurfacing arthroplasty seems to be a good solution for young, active people who require a hip prosthesis, with the large head of the implant reducing the risk of dislocation, and a relatively short time (approximately 3 months) before physical activity (including sports) can be resumed following the procedure. The limited extent of bone resection from the proximal end of the femur facilitates a possible future revision arthroplasty.

However, due to a number of critical reports presenting doubts as to the actual role of resurfacing arthroplasty in clinical practice, it seems that also male patients should be offered alternative surgical hip replacement options, by being presented not only the benefits of a given approach but also its risks [21, 23, 24].

Nevertheless, the role of resurfacing arthroplasty in current clinical practice is very limited and the procedure continues to be used in only a handful of centers.

\section{Neck-sparing arthroplasty}

Other types of hip arthroplasty implants are necksparing or neck-retaining, prostheses. Their use preserves the native bone in the femoral neck. During the procedure, a subcapital femoral resection is performed, i.e. the femoral neck is cut off very close to the head. One example of a neck-saving implant is the Spiron ${ }^{\circledR}$ prosthesis.

Following femoral head resection, a short shaft is screwed into the neck of the femur, onto which the ball of the prosthesis is then mounted.

Spiron ${ }^{\circledast}$ prostheses have been developed primarily with young patients in mind. They are ideal for patients who, due to their young age, face at least one revision surgery in the future. These prostheses ensure a greater stability of the implant stem in the native bone and reduce stresses at the prosthesis-bone interface, while preserving flexibility.

Unlike conventional long-stem uncemented implants, Spiron ${ }^{\circledR}$ prostheses help preserve natural stress distribution within the femur, which limits bone resorption at the implant-bone interface. Spiron ${ }^{\circledR}$ prostheses are made of a corundum blasted titanium-vanadium alloy and covered with a calcium phosphate coating, which facilitates their integration into native bone tissue.

Moreover, the postoperative rehabilitation period following Spiron ${ }^{\circledR}$ prosthesis implantation proved to be shorter than that following conventional total hip arthroplasty. Additionally, follow-up studies demonstrated increased trabecular reinforcement of the femoral neck [25] (Figure 1).

\section{Short-stem prostheses}

Another group of arthroplasty implants are shortstem prostheses, whose implantation requires the removal of the femoral head and part of its neck. 


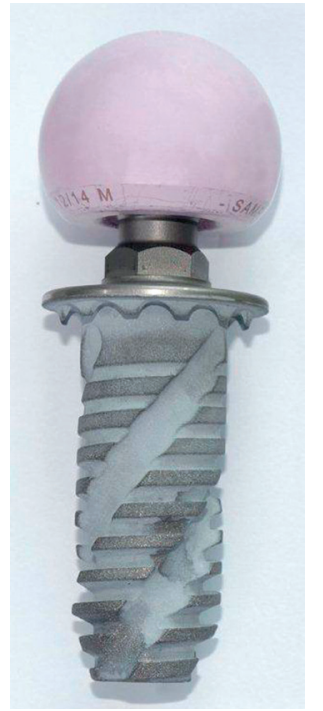

Figure 1. Spiron ${ }^{\circledR}$ prosthesis

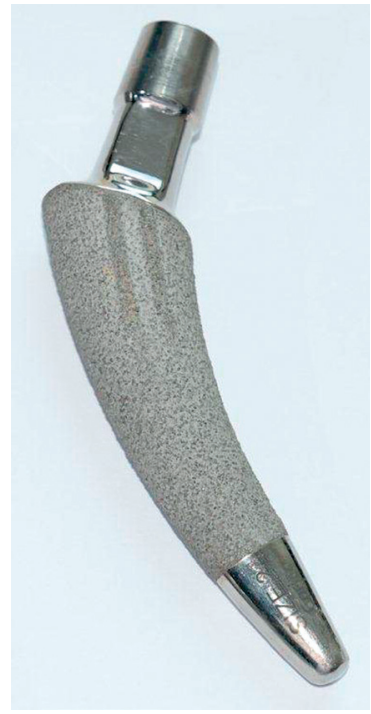

Figure 2. MiniHip ${ }^{\mathrm{TM}}$ prosthesis
The use of a short stem ensures a more natural proximal stress distribution at the implant-bone interface.

The greatest advantage of this implant type results from the fact that a short stem preserves native bone of the proximal end of the femur (bone resection is maximally limited). One example of a short-stem prosthesis is MiniHip ${ }^{\mathrm{TM}}$, also classified as a "partial collum" stem [26]. The composition of short-stem implants is unique, comprising a titanium alloy with a brushite coating. Brushite (BONIT ${ }^{\circledR}$ ) is an amorphous calcium phosphate characterised by a more rapid resorption, which accelerates implant osseointegration.

The stem surface texture increases the area of the implant-bone interface and directly increases primary implant stability (Figure 2).

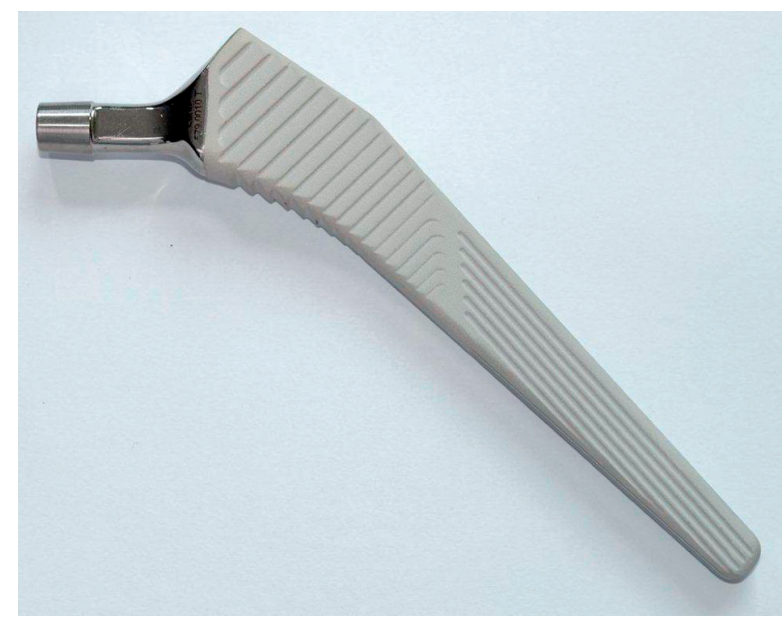

Figure 3. A long-stem cementless implant

\section{Conventional, long-stem prostheses}

The last type of prostheses consists of conventional long-stem implants. Following resection of the femoral head and neck, the long-stem prosthesis is anchored in the proximal and/or distal part of the femoral canal. Femur preparation involves cancellous bone removal or, more commonly, compaction with the use of special broaches shaped like the implant stem. Subsequently the prosthesis stem is implanted into the prepared femoral canal. In the case of a cemented prosthesis the femoral canal must be thoroughly cleared of cancellous bone. The implant stem is then anchored with the use of bone cement. The surgeon must closely monitor the thickness of the cement layer surrounding the stem and seal the femoral canal distal to the stem to prevent cement from spreading too far into the bone. Proper sealing is typically achieved with a special polyethylene stopper. Subsequently, the cement is vacuum-mixed to eliminate any air being trapped within. In the case of a cementless anchoring technique, the stem must be integrated with the native bone to the extent ensuring maximum stability. During the procedure, care must be taken not to crack the bone (Figure 3).

\section{The ball of the prosthesis}

While discussing the technical aspects of hip implant structure we should not omit the structure of the femoral head component, because it is mainly its structure and function that ultimately determine the everyday functioning of patients.

One important aspect is the size of the prosthetic head (ball). It is generally believed that larger prosthesis balls used during the procedure ensure a greater hip joint stability, lower risk of dislocation, and reduced long-term wear. One interesting solution is a bipolar (double-bearing, "ball within a ball") prosthesis, where a smaller head is placed inside a larger (typically polyethylene) head, which in turn articulates with the acetabulum.

Implant heads are typically composed of metal alloys, but they can also be ceramic. Ceramic surfaces - in the case of both acetabular inserts and prosthesis heads - would seem to be optimal as they undergo minimal wear. However, the use of ceramic material has its disadvantages; one of which is that, although tough and generally durable, the material is not flexible, which increases the risk of cracks. Moreover, the use of a ceramic head requires the acetabular component to be absolutely perfectly set within the pelvic bone (Figure 4).

\section{The acetabular component of the prosthesis}

The head of the prosthesis is in direct contact with the cup, or acetabulum. The acetabular structure may vary depending on the head and prosthesis type. 
The acetabular cups used in hip arthroplasty can be cemented or cementless [27]. Sometimes, depending on the manufacturer, a given prosthesis may include a cemented stem, while the acetabulum is anchored by osseointegration (structural fusion with bone) or vice versa. These are hybrid prostheses [27, 28].

Cemented acetabular cups are typically formed by a single polyethylene component. Polyethylene is an ultra-high-molecular-weight material with a vast range of potential uses. The high molecular weight helps to easily achieve the optimal spectrum of properties needed for various purposes. Polyethylene is characterised by excellent sliding properties and minimal wear, with high resistance to stress corrosion cracking, which makes the material suitable for medical purposes [28].

The addition of antioxidants, typically in the form of vitamin E, considerably increases the durability of polyethylene and reduces its rate of wear.

Cementless acetabular cups typically have two components - a metal part anchored directly to the bone and an insert that can be polyethylene, ceramic, or - sporadically - metal. A number of manufacturers offer implants where one type of metal acetabulum can be combined with any insert, which is an indisputable advantage. Acetabular insert selection depends on various factors, especially on the age and activity level of the patient, but also on whether or not the metal acetabular cup can be properly set within the bone. Younger patients are typically offered ceramic inserts due to their minimal wear. One disadvantage of using ceramic inserts is the risk of cracking, which is fortunately very low. Moreover, the cost of ceramic components is significantly higher. Polyethylene inserts are the most common, and are characterised by good sliding properties; modern manufacturing technologies significantly reduce their wear. One significant advantage of polyethylene inserts is the possibility of using asymmetric inserts, with one side of the insert raised above the metal cup, which provides additional stability and protects against prosthesis dislocation. This is particularly important if, for any reason, the metal acetabular cup cannot be set in the bone in its optimal position. Inserts are typically fit-pressed into the metal cup after it is anchored to bone; however, there are also monoblock inserts (e.g. Maxera ${ }^{\mathrm{TM}}$ ) that are permanently attached to the cup. Monoblock inserts have the advantage of being relatively thin, which results in a large internal diameter of the cup, which in turn allows for the use of a large implant head. Larger implant heads offer superior stability of the artificial joint. Sometimes, single-component uncemented acetabular cups are used, where the head of the prosthesis is in direct contact with the smooth metal internal surface of the cup (Protasul ${ }^{\circledR}$ ). The Protasul ${ }^{\circledR}$ cup is made of cobalt-chromium alloy containing chromium, molybdenum, nickel, magnesium, iron, carbon, nitrogen, and cobalt (marketed as Metasul $\left.{ }^{\circledR}\right)$ [28].

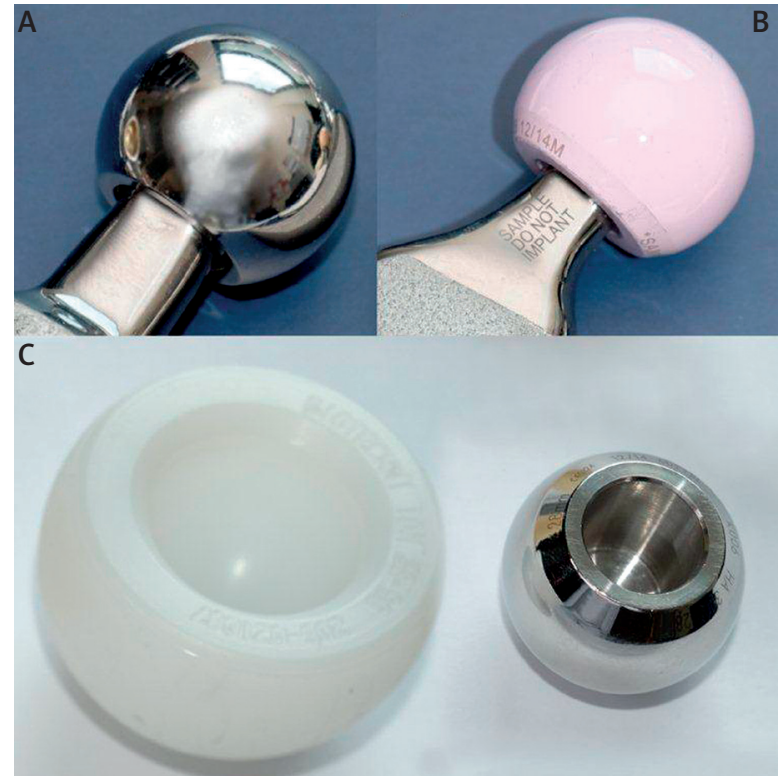

Figure 4. Prosthesis heads: A - metal, B - ceramic, C - bipolar

Uncemented acetabular implants are typically metal (the most commonly used metal is titanium). They can be screwed in or press-fitted. Press-fit acetabular components are sometimes additionally fixed with screws.

One example of an uncemented acetabular cup is the Allofit, with an external titanium layer with or without holes for additional fixation with titanium screws. Inside the metal component a polyethylene or ceramic insert is fitted [19].

Another example of uncemented acetabular component is CSF (Zimmer), which can have two or three inserts fitted within the metal cup. These inserts may be polyurethane, metal, or ceramic. The CSF acetabular component has a different shape - the part in contact with the pelvic bone is flat, and the whole acetabular component has the shape of a truncated cone with an external thread for fixation to the bone. This shape ensures appropriate distribution of forces exerted onto the pelvic bone, preventing excessive pressure to the fundus of the acetabulum. The fact that the acetabular cup is screwed into the osseous acetabulum allows for rapid osseointegration and high primary implant stability. This prosthesis is used especially in patients with dysplastic coxarthrosis. This is a condition where the osseous acetabulum does not develop normally and is too shallow [29].

The factors to be taken into account in the process of acetabular cup and insert selection include not only their appropriate size, but also the conditions for recreating the rotational axis of the joint, appropriate acetabular inclination, and depth of implant positioning [28].

Due to the fact that bone cement is not used as a fixation material in these implants, the diameter of 


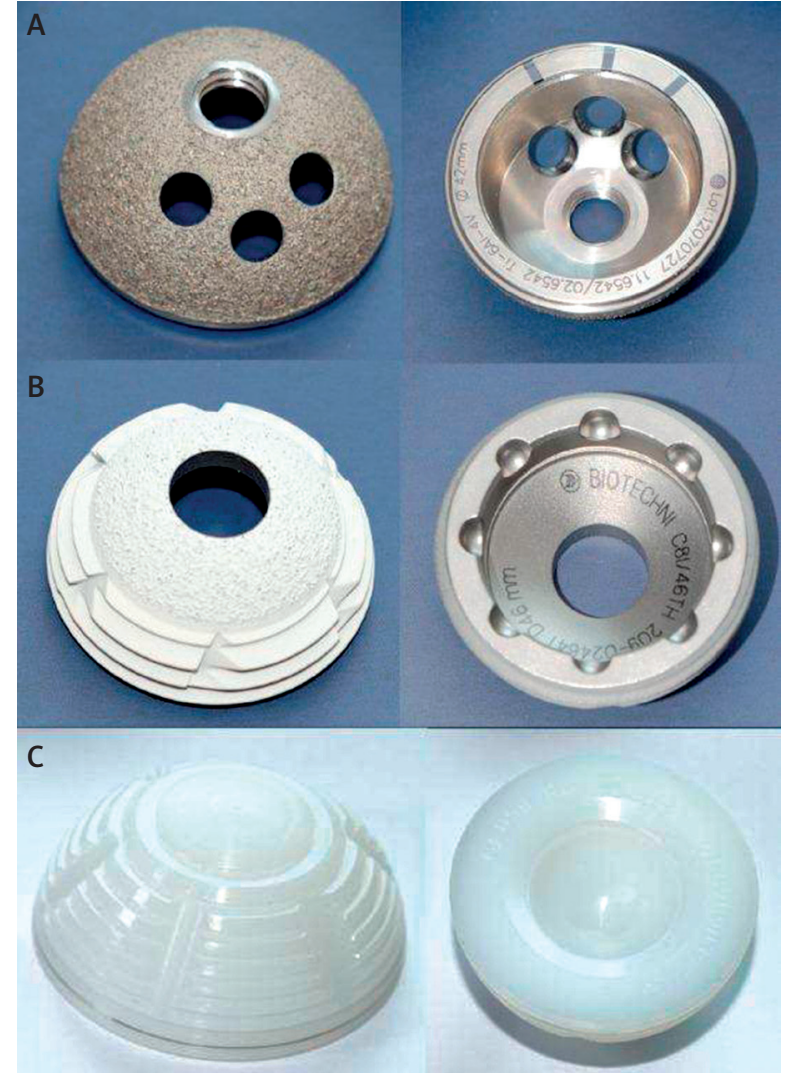

Figure 5. Acetabular cups: A - uncemented press-fit acetabular component with holes allowing for additional fixation with screws, B - uncemented screw-in acetabulum, C - cemented acetabulum

uncemented acetabular components is typically larger, to increase the contact surface area with the pelvic bone and prevent implant loosening.

Recent years have seen the development of effective methods increasing polyethylene durability against wear (with the use of special sterilisation methods and the addition of vitamin $\mathrm{E}$ as an antioxidant) $[17,27,28]$.

Notably, metal inserts or single-component metal acetabular cups are used relatively rarely (only in individual cases)

Ceramic inserts in hip arthroplasty are used mostly in younger and more physically active patients (Figure 5).

Custom-made hip prostheses are a special type of implants. Due to their very high cost (up to 30,000 PLN) their use is reserved for cases where a standard implant, even a modular-neck hip prosthesis, cannot be properly implanted due to significant deformity of the proximal femur and, possibly, the acetabulum as well. A model of the implant is 3-D printed based on computerised tomography (CT) scans showing the exact anatomy of the patient's hip, and a personalised prosthesis is made. The type of implant is determined by the patient's atypical anatomy and by the course of his or her disease that may affect long-term postoperative implant performance. Every custom-made implant is created as a result of close cooperation between the surgeon and a team of biomechanical engineers [30].

\section{The risk of hip arthroplasty complications}

Like all surgical procedures, hip arthroplasty is associated with a risk of perioperative complications. Some of them are general, others are implant-related and are directly associated with this type of procedure [31].

General complications include intraoperative bleeding, infections, venous thrombosis, pulmonary embolism, and nerve or vascular injury.

Implant-related complications include bone fracture, implant loosening, and dislocation. Complications can be also classified as early and late. Late complications typically involve implant dislocation or loosening, and the most common early complication is an infection.

Early complications typically require aggressive treatment. Signs of an infection are an indication for immediate revision surgery, sometimes even implant removal. In such cases, a temporary implant (spacer) impregnated with and gradually eluting an antibiotic is used. This treatment is accompanied by several weeks of systemic antibiotic therapy, initially intravenous and then continued orally following the patient's discharge home.

After signs of infection resolve completely, the patient may qualify for re-arthroplasty. In such cases, the temporary spacer is removed and the patient receives a permanent prosthesis once again. Unfortunately, despite no signs of infection, these patients remain in a high-risk group for recurrent infections. If a periprosthetic infection develops gradually, without acute signs or symptoms, it generally leads to loosening of the implant. Every infection may be life threatening, as it may become generalised and lead to sepsis.

Implant dislocation may occur in the early or late postoperative period. Typical signs and symptoms of dislocation are pain, the inability to walk, and a shortened and usually externally rotated limb. Implant dislocation requires immediate reduction, which is possible in a hospital setting.

Periprosthetic fractures may occur due to differences in mechanical properties of bone and the implanted prosthesis. These fractures almost always require surgical treatment. Bone fragments are fixed with special systems using cables or clamps, which ensure bone stability despite the fact that the prosthetic stem remains inside.

\section{Causes of implant loosening; revision prostheses}

Despite considerable technological progress and the availability of a number of improved joint pros- 
theses, the fact is that one prosthesis is not always going to last until the end of the patient's life. This is due to both the wear of movable components of the implant and the age-related musculoskeletal changes, such as osteoporosis, the patient's body weight, and chronic comorbidities.

Implants have a tendency to loosen over time [32,33].

Aseptic loosening remains a problem in joint implant patients. This may be a result of periprosthetic bone resorption in response to the introduction of a foreign body. If this happens, the loosened implant components must be replaced, sometimes with the use of special revision systems, or components allowing for filling in the resorbed bone tissue. One example of such approach is the use of the Trabecular Metal revision system [28, 34], comprising variously shaped components made of porous tantalum, or other, similar systems where other metals are used, e.g. titanium or special steel and light metal alloys. There are high hopes for biotechnological solutions such as new materials, with mechanical properties similar to those of healthy bone and new processing techniques, e.g. 3-D printers that yield custom-made implants ideally suitable for individual defects.

Delays in prosthesis replacement may lead to significant destruction of the native bone, both on the side of the pelvis and the femoral shaft, which makes it difficult or even impossible to conduct revision arthroplasty [35].

It is difficult to estimate the period of time after which the implant will become loosened in a given patient $[32,33,36]$. If the initial operation was due to idiopathic osteoarthritis with moderate joint deformation, it is common for the prosthesis to perform well for 30 years. However, sometimes implant loosening occurs only a few years after the procedure. The risk of implant loosening is higher in some circumstances, for instance if the initial indication was rheumatoid arthritis or developmental dysplasia. Obesity and excessive physical activity may also accelerate implant damage.

\section{Hip arthroplasty following femoral neck fracture}

If the native acetabulum is not excessively damaged by a degenerative condition, hemiarthroplasty or bipolar hemiarthroplasty are performed [19]. These procedures involve replacement of the damaged femoral head only.

One historical example of such partial hip replacement is the Austin-Moore prosthesis used in the case of femoral neck fractures. The procedure involved cutting off the fractured femoral neck and implanting an uncemented one-piece metal component with a large head.

This technique was typically used in very elderly patients with a number of comorbidities, indicating a necessity to maximally limit surgical injury. This ar- throplasty technique had the advantage of short procedure duration and relatively minor surgical injury. The purpose of Austin-Moore prosthesis implantation was mostly to alleviate fracture-related pain and allow for rapid patient mobilisation. Recently, the use of this prosthesis dropped significantly due to the fact that in the case of any postoperative complications the entire component had to be replaced; moreover, the hard metal head can relatively quickly damage native acetabular cartilage. Nowadays, the AustinMoore prosthesis is of mostly historical significance.

The current management standard following femoral neck fracture is bipolar hemiarthroplasty, where an implant stem is anchored within the femur, with or without the use of bone cement. The stem ends with a small ball (head) that articulates with a metal cup, which serves as a larger head and is placed, but not fixed, in the native osseous acetabulum. This double-bearing structure offers significant benefits: 1) it reduces friction at the acetabular cartilage-implant head interface, 2) it preserves native acetabular cartilage, and 3) in patients with progressive acetabular degeneration due to cartilage layer damage by the metal head, it allows for replacement of the large, double-bearing (or "ball within a ball") head with a new smaller head fitting into a new, implanted acetabular cup (while leaving the implant stem intact). Sometimes, the inner head remains as the final head of the prosthetic joint. This solution reduces surgical injury by limiting the procedure to head replacement and acetabular cup implantation, and eliminating any procedures involving the implant stem within the femoral shaft (Figure 6).

The standard prosthesis for total hip replacement can be used in femoral neck fractures, as well as in degenerative joint damage.

This article does not discuss the issue of oncological, post-resection prostheses, as this is a separate and extensive topic.

\section{Patient mobilisation following hip arthroplasty}

Hip arthroplasty is the ultimate treatment for hip joint degeneration. However, it is only one of the elements of a comprehensive treatment process, with a very significant role being played by physical rehabilitation. It is important to begin this process even before surgery - with pre-operative counselling. Patients who are better informed about their treatment options and receive sufficient encouragement tend to more purposefully and actively participate in postoperative rehabilitation [37-40]. Pre-operative counselling sessions may be used to teach the patient how to move under the new circumstances, how to use walking aids, and how to take appropriate precautions both in the hospital and at home. This is also a period when patients have an opportunity to pre- 


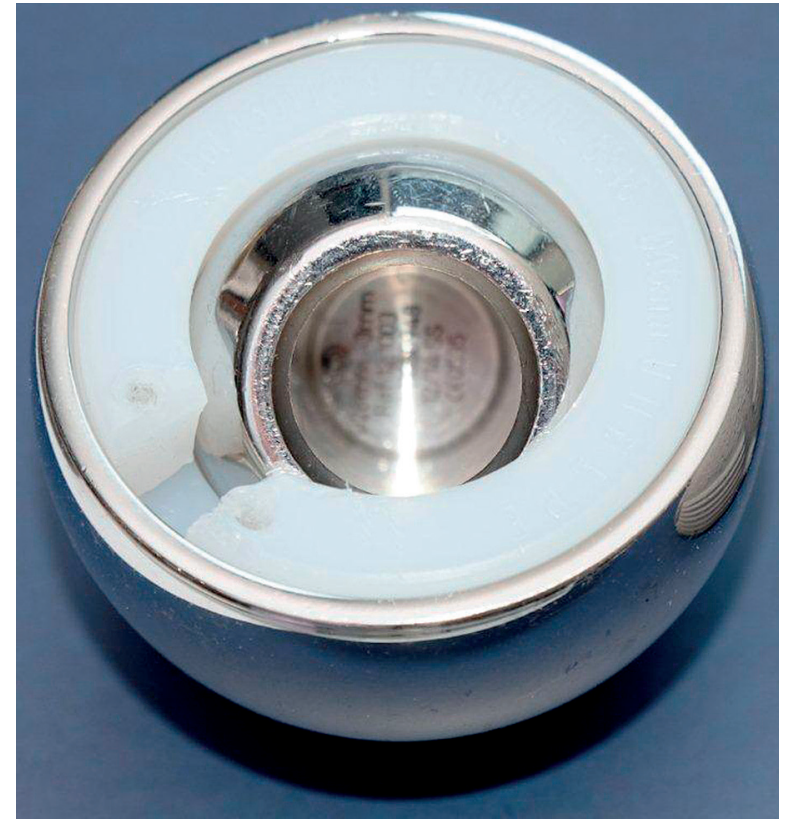

Figure 6. Double-bearing, or "ball within a ball" bipolar prosthesis

pare their home based on instructions given by their physical therapists on clearing walking paths and introducing any appliances for unobstructed walking during rehabilitation.

During the immediate post-operative period, patients remain in bed with a triangular pillow placed between their legs. This abduction pillow is to prevent unrecommended movements, including rotation of the operated limb, which would be harmful in this period. On the second day, the patients undergo upright mobilisation - first, they are helped up into a sitting position, then into a standing position, and they relearn how to walk with the help of a physical thera-

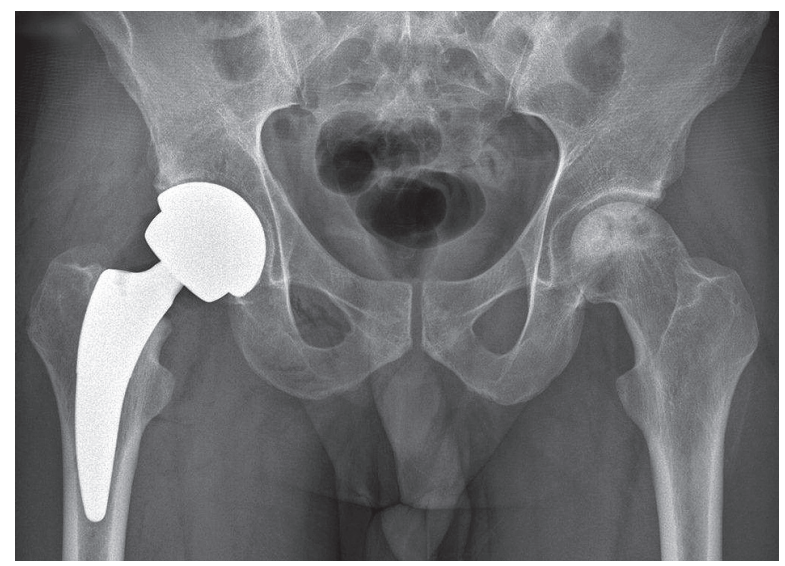

Figure 7. The Maxera ${ }^{\mathrm{TM}}$ acetabular system with Fitmore ${ }^{\circledR}$ hip stem and a large ( $44 \mathrm{~mm}$ ) ceramic ball implanted in a 32-yearold man due to avascular necrosis of the femoral head pist - first, with the use of a walking frame, then with elbow crutches. Most patients learn to use the walking aids well and walk longer and longer distances in subsequent postoperative days. The gradual increase in weight bearing on the operated limb depends on factors such as the prosthesis fixation method. The use of cemented implant components allows for early weight bearing. Until recently, full weight bearing in the case of cementless anchoring, used to be discouraged until 6-8 weeks after surgery. However, this period has shortened radically and the commonly established practice is becoming shorter to recommend full weight-bearing as soon as possible, in some cases even on the first or second postoperative day.

Walking exercises and practice in performing everyday activities on their own should be initiated at the hospital ward in which the patients underwent surgery. When the patients are able to walk far enough to reach the bathroom, while supervised, they may try sitting down on the toilet. Elevating the toilet seat by the use of a seat cover placed on top ensures maintaining a desired angle between the thigh and the trunk while sitting, to prevent inappropriate flexion and relative positioning of implant components [41-44]. Proper perioperative mobilisation has a significant effect on the rapidity of full physical recovery, considerably reduces the duration of hospital stay and post-operative convalescence, and minimises the risk of complications.

\section{Conclusions}

The type of prosthesis to be used in a particular patient depends mostly on the indications for surgery, the condition of the patient's bones, the patient's age and general health status, the level of physical and social activity, and the presence of comorbidities and any other specific risk factors.

For example, a neck-sparing implant may be more appropriate for a younger, more active patient, while a long-stem implant may be more appropriate for an older patient whose physical activity is limited by other factors.

Patients with inadequate bone tissue structure (e.g. in osteoporosis) typically receive cemented prostheses.

In the case of hip arthroplasty it is important to consider the material of the bearing surfaces, i.e. the internal surface of the acetabular cup and the surface of the ball (or head) of the implant.

Which hip joint prosthesis is the best? In light of the above, the answer seems obvious - the best prosthesis for one parson may not be the best prosthesis for someone else. For a young and active patient with good bone structure the optimal solution seems to be a short-stem or neck-sparing prosthesis with a large ceramic head and an acetabular cup with a ceramic insert (Figure 7). 
A 70-year-old patient usually receives a classic, typically cementless, long-stem prosthesis with a relatively large head and a polyethylene-lined acetabulum. Older, approximately 80 -year-old patients diagnosed with osteoporosis typically receive cemented long-stem prostheses. The use of bone cement facilitates a more rapid patient mobilisation, and weight bearing on the operated limb is possible practically on the second postoperative day.

The selection of the optimal surgical approach and a suitable prosthesis, as well as close cooperation between the patient, surgeon, and physical therapist helps achieve optimal treatment outcomes, minimises the risk of complications, ensures optimal performance status, and frees the patient of the pain associated with osteoarthritis of the hip.

\section{Conflict of interest}

The authors declare no conflict of interest.

\section{References}

1. Kosowski A, Teter Z, Paszkiewicz J. Analiza ilościowo-finansowa endoprotezoplastyk dużych stawów przeprowadzonych $\mathrm{w}$ Polsce $\mathrm{w}$ roku 2010 sporządzona na podstawie danych zgromadzonych $\mathrm{w}$ Centralnej Bazie Endoprotezoplastyki Narodowego Funduszu Zdrowia. Kwart Ortop 2011; 4: 305-13.

2. Sienkiewicz D, Golec E, Nowak S, et al. Ocena wyników odległych leczenia operacyjnego złamań okołokrętarzowych kości udowej z zastosowaniem dynamicznego stabilizatora biodrowego. Przegl Lek 2008; 65: 32-6.

3. Magnuszewski JL, Hagner W, Wojtecki B. Odległe wyniki leczenia złamań szyjki kości udowej metodą endoprotezoplastyki połowiczej Austin-Morre’a. Kwart Ortop 2004; 3: 175-7.

4. Wierusz-Kozłowska M, Markuszewski J. Choroba zwyrodnieniowa stawów. In: Marciniak W, Szulc A. (eds.) Wiktora Degi ortopedia i rehabilitacja. Wydawnictwo Lekarskie PZWL, Warsaw 2003; 51: 274-89.

5. Panasiuk M, Kmieciak M. Historia i rozwój protezoplastyki biodra. Cz. III. Kwart Ortoped 1994; 1: 42-9.

6. Kwiatkowski K. Choroba zwyrodnieniowa stawu biodrowego. Stand Med 2004; 12: 1277-81.

7. Bruckle W. Reumatoidalne zapalenie stawów. Rozpoznanie przebieg leczenie. Interspar, Warsaw 2013.

8. Lewandowski B, Sierakowski S, Kita K. Biodro - przyczyny najczęstszych dolegliwości. Nowa Med 2002; 2: 31-5.

9. Sierakowski S. Choroba zwyrodnieniowa stawów na progu XXI wieku. Nowa Med 2002; 2: 2-3.

10. Górecki A. Problemy leczenia zmian zwyrodnieniowych stawu biodrowego i kolanowego. In: Dekada kości i stawów. Rok Pierwszy, Kraków 2000; 22-32.

11. Kwiatkowski K. Choroba zwyrodnieniowa stawu biodrowego. Stand Med 2004; 12: 1277-81.

12. Sims K. Rozwój choroby zwyrodnieniowej stawu biodrowego - konsekwencje dla leczenia zachowawczego. Rehab Med 2000; 4: 92-103.

13. Dziekońska M, Latosiewicz R, Kulikowska A. Pielęgnowanie pacjenta po endoprotezoplastyce stawu biodrowego. Hygeia Public Health 2013; 48: 355-9.

14. Wilk M. Indywidualizacja procesu rehabilitacji u osób w wieku podeszłym po artroplastyce biodra - studium dwóch przypadków. Stud Med 2008; 10: 43-6.
15. D'Apuzzo MR, Pao AW, Novicoff WM, et al. Age as an independent risk factor for postoperative morbidity and mortality after total joint arthroplasty in patients 90 years of age or older. J Arthroplasty 2014; 29: 477-80.

16. Jędrzejczak M, Synder M, Marciniak M, et al. Ocena jakości życia pacjentów po alloplastyce stawu biodrowego. Kwart Ortop 2001; 4: 228-36.

17. Strzelec-Nowak D. Ogólnoustrojowa i miejscowa odpowiedź immunologiczna podczas zakażenia endoprotez stawu biodrowego. Rozprawa doktorska. UM w Lublinie, Katedra i Zakład Mikrobiologii Lekarskiej II Wydział Lekarski z Oddziałem Anglojęzycznym, Lublin 2014.

18. Gągała J, Mazurkiewicz T. Zastosowanie małoinwazyjnego podwójnego dostępu operacyjnego w bezcementowej endoprotezoplastyce stawów biodrowych. Kwart Ortoped 2013; 1: 41-8.

19. Madej T. Modelowanie strefy ruchowej endoprotezy stawu biodrowego w aspekcie biomateriałów. Rozprawa doktorska. AGH im. St. Staszica Wydział Inżynierii Mechanicznej i Robotyki, Krakow 2008.

20. Karuś A. Analiza przyczyn zwichnięć endoprotez stawu biodrowego. Rozprawa doktorska. CM UJ, Wydział Lekarski, Krakow 2010.

21. Płomiński J, Kwiatkowski K. Historia protezoplastyki stawu biodrowego. Pol Merkuriusz Lek 2007; XXII: 83-6.

22. Tylman D. Wskazania do wymiennej plastyki stawów w uszkodzeniach pourazowych. In: Traumatologia narządu ruchu. Vol. 2. Tylman D, Dziak A (eds.). Wydawnictwo Lekarskie PZWL, Warsaw 2013; 16: 574-6.

23. Smith AJ, Dieppe P, Howard PW, et al. Failure rates of metal-on-metal hip resurfacings: analysis of data from the National Joint Registry for England and Wales. Lancet 2012; 380: 1759-66.

24. Catelas I, Lehoux EA, Hurda I, et al. Do patients with a failed metal-on-metal hip implant with a pseudotumor present differences in their peripheral blood lymphocyte subpopulations? Clin Orthop Relat Res 2015 Sep 1 [Epub ahead of print].

25. Birkenhauer B, Kistmacher H, Ries J. Conception and first results of the Spiron cementless femoral neck screw prosthesis. Orthopade 2004; 33: 1259-66.

26. Jerosch J, Grasselli C, Kothny PC, et al. Reproduction of the anatomy (offset, CCD, leg length) with a modern short stem hip design - a radiological study. Z Orthop Unfall 2012; 150: 20-6.

27. Płomiński J. Aseptyczne obluzowania panewki protezy stawu biodrowego. Rozprawa habilitacyjna. Wojskowy Instytut Medyczny, Warsaw 2006.

28. Kokoszka P. Wieloaspektowa analiza wyników bezcementowej endoprotezoplastyki stawu biodrowego z zastosowaniem trzpienia Zweymüllera oraz stożkowej panewki wkręcanej. Rozprawa doktorska. Uniwersytet Medyczny w Poznaniu, Poznan 2012.

29. Drobniewski M, Synder M, Kozłowski P, et al. Odległe wyniki bezcementowej alloplastyki stawu biodrowego w koksartrozie dysplastycznej. Wiad Lek 2005; 58: 4-9.

30. Bert JM. Custom total hip arthroplasty. J Arthroplasty 1996; 11: 905-15.

31. Safran MR, Ranawat AS, Sekiya JK, et al. Artroskopia stawu biodrowego. Elsevier Urban\&Partner, Wroclaw 2013.

32. Cobo J, Del Pozo JLD. Prosthetic joint infection: diagnosis and management. Expert Rev Anti Infect Ther 2011; 9: 787-802.

33. Wang W, Ouyang Y, Poh CK. Orthopaedic implant technology: biomaterials from past to future. Ann Acad Med 2011; 40: 237-44. 
34. Mohaddes M, Rolfson O, Kärrholm J. Short-term survival of the trabecular metal cup is similar to that of standard cups used in acetabular revision surgery. Acta Orthop 2015; 86: 26-31.

35. Trampuz A, Zimmerli W. Prosthetic joint infections: update in diagnosis and treatment. Swiss Med Wkly 2005; 135: 243-51.

36. Berbari EF, Hanssen AD, Duffy MC, et al. Risk factors for prosthetic joint infection: case-control study. Clin Infect Dis 1998; 27: 1247-54.

37. Kózka M. Wybrane standardy opieki pielęgniarskiej. Instytut Pielęgniarstwa CM UJ, Krakow 1997.

38. Dorr LD. Alloplastyka stawu biodrowego. Elsevier Urban \&Partner, Wroclaw 2009.

39. Majda A, Walas K, Gawełek A. Jakość życia pacjentów z chorobą zwyrodnieniową stawów biodrowych. Problemy Pielęgniarstwa 2013; 21: 29-37.

40. Piecuch R, Targońska-Stępiak B, Majdan M. Aktualne poglądy na leczenie choroby zwyrodnieniowej stawów. Lekarz 2008; 6: 81-8.

41. Hrycaj PZ, Łącki JK. Od zwyrodnienia do zapalenia współczesne poglądy na patogenezę choroby zwyrodnieniowej stawów. Nowa Med 2002; 2: 7-15.

42. Kapała W. Pielegnniarstwo w chirurgii. Wybrane problemy z praktyki pielęgniarskiej oddziałów chirurgii ogólnej. Czelej, Lublin 2006; 193-6.

43. Malinowska K, Dega W. Rehabilitacja medyczna. Wydawnictwo Lekarskie PZWL, Warsaw 1998.

44. Dziak A. Ćwiczenia usprawniające w uszkodzeniach kości i stawów. Wydawnictwo Lekarskie PZWL, Warsaw 1990.

\section{Address for correspondence:}

Tomasz Poboży MD

Medicover Hospital

al. Rzeczypospolitej 5, 02-972 Warsaw, Poland

Phone: +48 600980648

E-mail: tomasz.pobozy@onet.pl 